\title{
The Paris System - A new insight into reporting urine cytology
}

\author{
Ghosh $\mathrm{A}^{1}$ \\ ${ }^{\prime}$ Department of Pathology, Manipal College of Medical Sciences, Pokhara, Nepal.
}

\author{
Keywords: \\ Urothelial carcinoma; \\ High grade; \\ Low grade; \\ Inadequate
}

\begin{abstract}
Urine cytology helps in the diagnosis of urothelial malignancies. There were no universally accepted reporting system despite several systems were suggested in the past. As a part of first international effort to standardize urine cytology, The Paris System Working Group was formed comprising pathologists and urologists who met in 2013 at the International Congress of Cytology in Paris and proposed The Paris System (TPS). It was unanimously decided that the main aim of urine cytology was to detect high grade urothelial carcinoma. TPS consists of 7 diagnostic categories and also tries to define several morphological criteria. TPS Atlas was published in 2016. This article tries to summarize and highlight essential points of The Paris System.
\end{abstract}

\section{INTRODUCTION}

Urine cytology is a cheap simple and noninvasive test to detect urothelial malignancy. Urine cytology samples comprise a sizable portion of nongynecologic cytology in any pathology laboratory and urologists depend on it as a supplement to the endoscopic and radiographic evaluation of urinary tract to detect urothelial malignancy. ${ }^{1}$ Although cystoscopy is the "gold standard" diagnostic tool for detection of bladder cancers it is not perfect and its diagnostic accuracy depends on experience of the urologist and the cytopathologist. ${ }^{2}$

\section{Correspondence:}

Dr. Arnab Ghosh, MBBS, MD

Department of Pathology

Manipal College of Medical Sciences, Pokhara, Nepal

Email:docarnab2k@yahoo.com
Way back in 1945 Papanicolaou and Marshall published their study on urine sediment and suggested that microscopic evaluation of exfoliated cells in urine might be a useful method to detect urinary tract malignancy. ${ }^{1,3}$ Since then there have been numerous studies on utility and reproducibility of urine cytology. It is well recognized that different studies have shown problems with widely varying sensitivity and accuracy of urine cytology reports due to several factors viz., inadequate sampling and cellularity, cellular degeneration, inadequate cellular exfoliation yield in low grade neoplasms, and subjective variation due to lack of universal standardized reporting criteria. ${ }^{1}$

Effort towards a universally acceptable reporting system started when Papanicolaou proposed 5 tier classification system in 1947. ${ }^{4}$ Later Koss LG et al in 1973, Murphy WM 
Table 1 : Different diagnostic categories of The Paris System (TPS) and chair of each subgroup ${ }^{12}$

\begin{tabular}{lll}
\hline \multicolumn{1}{c}{ Diagnostic Categories } & \multicolumn{1}{c}{ Chair of the subgroup } \\
\hline 1 & Nondiagnostic / Unsatisfactory & \\
2 & Negative for High Grade Urothelial Carcinoma (NHGUC) & Dr Dorothy Rosenthal, John Hopkins \\
3 & Atypical Urothelial Cell (AUC) & Dr Guliz Burkan, Lyola University \\
4 & Suspicious for High Grade Urothelial Carcinoma (SHGUC) & Dr Fadi Brimo \\
\hline 5 & High Grade Urothelial Carcinoma (HGUC) & Dr Momin Siddiqui, Emory University \\
6 & Low Grade Urothelial Neoplasm (LGUN) & Dr Eva Wojcik, Lyola University \\
7 & Other - primary and secondary malignancies and miscellaneous lesions & Dr Rana S. Hoda, Weill Cornell
\end{tabular}

et al in 1984, Ooms EC et al in 1993 came up with their own classification systems. ${ }^{4-7}$ Then in 2003 Papanicolaou Society of Cytopathology Task Force Classification was published. This classification included the term "atypical urothelial cells" though its criteria were not conclusive and also mentioned about ancillary studies like FISH on urine cytology specimens. ${ }^{1,8,9}$ Later in 2013, Owens CL et al published Hopkins template for Urine Cytology. ${ }^{10}$ These different classification systems for urothelial neoplasms have been summarized in Fig $1 .{ }^{10}$ Unfortunately, the discrepancy, controversy and the lack of uniformity in reporting urine cytology continued. ${ }^{8}$ An international tele-cytologic quiz on urine cytology was conducted by Glatz et al and $48.4 \%$ participants misdiagnosed high grade urothelial carcinoma as reactive lesion, $54.5 \%$ misdiagnosed viral cytopathic effect as high grade, $79.2 \%$ misdiagnosed basal cells in bladder wash as atypia and $64 \%$ misdiagnosed low grade atypia as benign. ${ }^{11}$

Being encouraged by the success and widespread international acceptance of The Bethesda System for cervical cytology, an international panel of recognized cytopathologists, surgical pathologists and urologists with interest in urinary tract cytopathology convened in Paris in May 2013 at the 18th International Congress of Cytology organized by the International Academy of Cytology. It was the first effort at international level to standardize the urine cytology. The aim of this Paris System Working Group was to discuss ways to improve and standardize the reporting of urine cytology as well as to define specific morphological criteria. This led to a new system named as "The Paris System (TPS) for reporting urine cytology" which is somewhat comparable to The Bethesda Systems for reporting cervical and thyroid cytology. After the initial meeting, a web based survey including several pathologists was conducted by the International Academy of Cytopathology, American Society of Cytopathology and the problematic areas which were noted in the survey were considered by the working group. The group also worked on identifying the value of ancillary testing in the screening and diagnosis of urinary neoplasms. The Paris System of reporting and the Atlas were published in early 2016 by Springer press. ${ }^{1,12}$ The Atlas has detailed discussions and explanations as well as many illustrations. The diagnostic categories for The Paris System and the chairperson of each subgroup have been shown in Table 1 . Approach in urine cytology reporting according to TPS has been simplified and summarized in Table 2.

According to the current understanding urothelial carcinomas (UC) are divided into two major groups viz., low grade and high grade. These two groups have different morphology, biologic behavior and also different genetic pathways. The genetic pathways have been summarized in Fig 2. Approximately $80 \%$ of UCs arising in urinary bladder are non-muscle invasive tumors (WHO/ISUP stage $\mathrm{pTa} / \mathrm{T} 1)$ and categorized as low grade urothelial carcinoma (LGUC) on biopsy. The genetic path LGUC follows is called "hyperplastic pathway". It includes mutation in CDKN2A (cyclin dependent kinase inhibitor 2A) and FGFR-3 (fibroblast growth factor receptor-3). Low grade urothelial carcinoma has a good prognosis but may show high recurrence rate. The other path is known as "dysplastic path" which may lead to high grade urothelial carcinoma (HGUC) and to carcinoma in situ (or flat carcinoma) in $<10 \%$ cases. High grade urothelial carcinoma is biologically aggressive and may go to WHO/ISUP stage T2 or higher. Several genetic mutations have been found to be associated with this pathway, the most consistent being mutation in TP53. Current studies suggest that only $<1-5 \%$ of LGUC may go to HGUC which raises the suspicion that these two are different disease entities rather than a continuum of the same process. ${ }^{12-15}$ Considering this concept the Paris System Working Group has redefined the primary purpose of urine cytology. The new reporting system concentrates on detecting HGUC mainly and minimizing the detection of LGUC on cytology, as the cytological sensitivity is high for the former and is questionable for the latter. The low sensitivity for LGUC is because these lesions yield very few cells, the cells are morphologically closely similar to normal benign urothelium and universal morphological criteria could not be made. ${ }^{12}$

Urine cytology can be used to screen for urothelial malignancy in persons with high risk factors (e.g., older age, male, smoking history, occupational exposure to carcinogens) and those with unexplained irritative urinary symptoms, and to monitor known cases post treatment. Urine cytology as the initial diagnostic test in patients with hematuria is disputed as most hematuria are not due to a neoplasm. However in correct clinical context urine cytology may be useful in hematuria cases. Urine cytology also can be used to detect infections especially polyoma BK 
Table 2. Summary of approach in Urine cytology reporting according to The Paris System

\begin{tabular}{|c|c|c|c|c|}
\hline \multirow{9}{*}{$\begin{array}{l}\text { Cytologic } \\
\text { atypia } \\
\text { present }\end{array}$} & \multirow{4}{*}{ 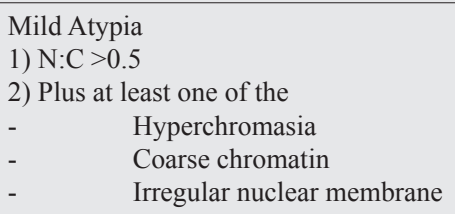 } & \multirow{4}{*}{$\begin{array}{l}\text { Fibrovascular core present? } \\
\text { Any reason for mild atypia ? ( e.g., treat- } \\
\text { ment related?) }\end{array}$} & Absent & Report as Negative \\
\hline & & & Present & Report as LGUN \\
\hline & & & Yes & Report as Negative \\
\hline & & & No & Report as AUC \\
\hline & & \multirow{5}{*}{ Quantity / numbers of these cells } & $<5-10$ cells & Report as Suspicious of HGUC \\
\hline & 1) $\mathrm{N}: \mathrm{C}>0.7$ & & \multirow{4}{*}{ Many } & \multirow{4}{*}{ Report as HGUC } \\
\hline & $\begin{array}{l}\text { 2) Hyperchromasia } \\
\text { 3) Plus at least one of the }\end{array}$ & & & \\
\hline & - $\quad$ Coarse chromatin & & & \\
\hline & Irregular nuclear membrane & & & \\
\hline
\end{tabular}

virus in patients with renal transplant. ${ }^{8,12}$

Voided urine sample is the commonest type of sample for detecting UC. Second morning sample is preferred to the first morning sample as the latter shows more cytological degenerative changes due to overnight stagnation. Catheterized urine samples lack any contamination and squamous cells from lower urogenital area and so are better than voided samples especially in female patients. Wash , barbotage and brush samples can be obtained during cystoscopy from urinary bladder (most common) and also from ureter or renal pelvis. They provide better sampling and higher cellularity. ${ }^{8} 12$ Various methods used for urinary cytology include ThinPrep, which is most commonly used in U.S., CytoSpin, SurePath, AutoCytePrep, Nitrocellulose membrane filtration, Millipore filtration, and MonoPrep. ThinPrep is the most commonly used method in U.S. as it gives better morphological details, cleaner background and less obscuring inflammation. ${ }^{8} 12$

\section{Sample adequacy}

Sample adequacy is a controversial topic in any type of cytopathology including urine cytology and includes quantitative (cellularity, volume) and qualitative (morphology details, degeneration, obscuring elements, artifacts) nature of the specimen. Keeping in mind that the cytomorphology diagnosis is the most important aspect, it was decided in TPS that any sample with atypical, suspicious or malignant cells should be called adequate and reported. So the question of inadequacy comes only when the sample does not show any findings indicative of any disease process. Studies on volume, types of sample, sampling method, cellularity of urine samples are limited and conclusions are varied. TPS has published a flowchart as a guideline for cytologists to follow (fig. 3). It has also been stated that if urothelial cells are obscured by any inflammation, blood, mucin, lubricant etc, then the sample should be called inadequate. TPS has proposed that in instrumented specimens, 2600 cells or 2 well visualized urothelial cells per high power field (HPF) in 10 consecutive HPFs (i.e. total of at least 20 cells in $10 \mathrm{HPFs}$ ) may be taken as adequacy criteria. ${ }^{12,16}$ In instrumented specimens where there are 10-20 cells/10 HPF should be reported as "satisfactory but limited by low cellularity" and those with $<10$ cells/10 HPFs should be under "unsatisfactory/ nondiagnostic". For voided urine samples, preliminary studies till date indicate that specimen more than $30 \mathrm{ml}$ are more likely to be cellular and/or satisfactory. ${ }^{17,18}$ TPS however does not recommend disqualifying a sample only on the basis of volume. TPS hopes that future studies will be conducted on this unclear area of sample adequacy and currently suggests to follow the algorithm. ${ }^{12}$

\section{Negative for High grade urothelial carcinoma (NHGUC)}

In the new formulation majority of urinary tract specimens fall in this category. The most commonly seen cells are benign superficial urothelial cells followed by intermediate and basal cells which are more common in instrumented specimens. Other benign cells which may be seen under NHGUC include superficial squamous cells especially in female patients, benign glandular cells, benign urothelial tissue fragments, reactive urothelial cells / umbrella cells,

Table 3. Risk of malignancy and suggested management protocol for each subcategory as per the literature to date ${ }^{1}$

\begin{tabular}{lll}
\hline \multicolumn{1}{c}{ Category } & $\begin{array}{l}\text { Risk of malignancy, } \\
\%\end{array}$ & Management \\
\hline Unsatisfactory/nondiagnostic & $<5-10$ & repeat cytology, cystoscopy in 3 months if increased clinical suspicion \\
\hline Negative for high-grade urothelial carcinoma & $0-10$ & clinical follow-up as needed \\
\hline Atypical urothelial cells & $8-35$ & clinical follow-up as needed; potential use of ancillary testing \\
\hline Suspicious for high-grade urothelial carcinoma & $50-90$ & more aggressive follow-up, cystoscopy, biopsy \\
\hline High-grade urothelial carcinoma & $>90$ & more aggressive follow-up, cystoscopy, biopsy, staging \\
\hline Low-grade urothelial neoplasm & $\sim 10$ & need cystoscopy and biopsy to further evaluate grade and stage \\
Other malignancy & $>90$ & more aggressive follow-up, cystoscopy, biopsy, staging
\end{tabular}




\begin{tabular}{|c|c|c|c|c|c|c|c|}
\hline \multicolumn{6}{|c|}{ Cytologic Classification } & \multicolumn{2}{|c|}{ Histologic Classification } \\
\hline $\begin{array}{l}\text { Papanicolaou } \\
1947 \\
\text { (Papanicolaou } \\
\text { Classification } \\
\text { System) }\end{array}$ & Koss 1985 & $\begin{array}{l}\text { Murphy } \\
1984\end{array}$ & $\begin{array}{c}\text { Ooms \& } \\
\text { Veldhuizen } \\
1993\end{array}$ & $\begin{array}{c}\text { Layfield } \\
\text { et al } 2004 \\
\text { (Papanicolaou } \\
\text { Society of } \\
\text { Cytopathology) }\end{array}$ & $\begin{array}{l}\text { Hopkins } \\
\text { Template }\end{array}$ & $\begin{array}{c}\text { Mostofi \& Torloni } \\
1973 \text { (WHO) }\end{array}$ & $\begin{array}{l}\text { Epstein } 1998 \\
\text { (WHO/NSUP) }\end{array}$ \\
\hline ' & $\begin{array}{l}\text { Benign cells, } \\
\text { ATY } 1 \text { cells. } \\
\text { few clusters }\end{array}$ & Negative & Negative & Negative & NUAM & $\begin{array}{l}\text { Papilloma } \\
\text { TCC, grade } 1\end{array}$ & $\begin{array}{l}\text { Papilloma } \\
\text { PUNLMP } \\
\text { LGUC }\end{array}$ \\
\hline it & $\begin{array}{l}\text { Clusters, nuclear } \\
\text { elongation, } \\
\text { few ATY } 2 \text { cells }\end{array}$ & $\begin{array}{l}\text { Dysplastic } \\
\text { celts } \\
\text { Suspicious }\end{array}$ & $\begin{array}{l}\text { Atypical, } \\
\text { significance } \\
\text { uncertain } \\
\text { Suspicious }\end{array}$ & $\begin{array}{l}\text { Atypical } \\
\text { urothelial cells }\end{array}$ & $\begin{array}{l}\text { AUC-US } \\
\text { AUC-H }\end{array}$ & TCC. grade 2 & \\
\hline $\begin{array}{l}\text { N } \\
\text { v }\end{array}$ & $\begin{array}{l}\text { Malignant } \\
\text { turnor cells, } \\
\text { many ATY } \\
2 \text { cells }\end{array}$ & $\begin{array}{l}\text { Malignant } \\
\text { cells }\end{array}$ & $\begin{array}{l}\text { Neoplastic } \\
\text { cells present }\end{array}$ & $\begin{array}{l}\text { Urothelial } \\
\text { carcinoma }\end{array}$ & $\begin{array}{l}\text { Urothelial } \\
\text { carcinoma }\end{array}$ & TCC, arade 3 & HGUC \\
\hline
\end{tabular}

Abbreviations: ATY 1, atypical cells with hyperchromasia and predominantly round or oval contours; ATY 2, cells with hyperchromasia and nuclear membrane abnormalities; AUC-H, atypical urothelial cells cannot exclude high-grade urothelial carcinoma; AUC-US, atypical urothelial cells of uncertain significance; HGUC; highgrade papillary urothelial carcinoma, ISUP. International Society of Urological Pathology; LGUC, low-grade papillary urothelial carcinoma; NUAM, no urothelal atypia or dysplasia identified; PUNLMP, papiliay urothelial malignancy of uncertain malignant potential; TCC, transitional cell carcinoma; WHO, World Health Organization.

Figure 1: Evolution of cytological and histological classification for urothelial neoplasms ${ }^{10}$

renal tubular epithelial cells, cells with changes related to bladder/ renal stones, viral cytopathic changes (especially "decoy cell" due to polyoma BK virus), cells with instrumental artifact, post-treatment changes (radiotherapy, chemotherapy, immunotherapy/BCG instillation).

This category will comfort clinicians and patients as several cases, which would have been reported as "Atypical" earlier, will now fall under this category and thus will avoid unnecessary interventions. ${ }^{19}$ It is to emphasize that NHGUC does not rule out presence of low grade neoplasms, it only rules out presence of HGUC. ${ }^{12}$

\section{Atypical Urothelial Cell (AUC)}

This system tries to define and standardize the morphological criteria for atypia and minimize its random use. In the past the criteria of atypia have varied in different institutions and also among different pathologists in same department. Reports with terms like suspicious, atypical, indeterminate have often been dispatched which do not give any clear direction towards line of management. With the new system minor atypia is reported as NHGUC and significant atypia are shifted towards the next category that is Suspicious for HGUC. The criteria for this AUC category includes high $\mathrm{N}: \mathrm{C}$ ratio $>0.5$ in non-superficial and non- degenerated urothelial cell. In addition one of the following criteria must be present- mild to moderate nuclear hyperchromasia, irregular nuclear membrane, irregular coarse chromatin. (Table 2) Nuclear chromasia can be compared with a benign superficial urothelial cell (preferable) or an intermediate squamous cell. For "irregular nuclear membrane", the round shape and smooth contour of nuclei of normal urothelial cells can be used as internal control. ${ }^{12,19}$

\section{Suspicious for High Grade Urothelial Carcinoma (SHGUC)}

The cellular atypia which are significant (i.e., more than
AUC) but are still quantitatively short of calling it HGUC fall under this category. The compulsory criteria put forward by TPS for this category includes increased N:C ratio $>0.7$ (in contrast to $>0.5$ in AUC) and severe nuclear hyperchromasia along with at least one of the following criteria which includes irregular nuclear membrane, and coarse clumped chromatin. (Table 2) The number of these cells should be less than 5-10 in number. ${ }^{12}$ TPS also mentions that the cells with $\mathrm{N}: \mathrm{C}$ ratio between 0.5 to 0.7 may be considered as SHGUC if all other minor features are seen especially in voided urine sample or in patients with history of HGUC. Instrumentation may cause increase in

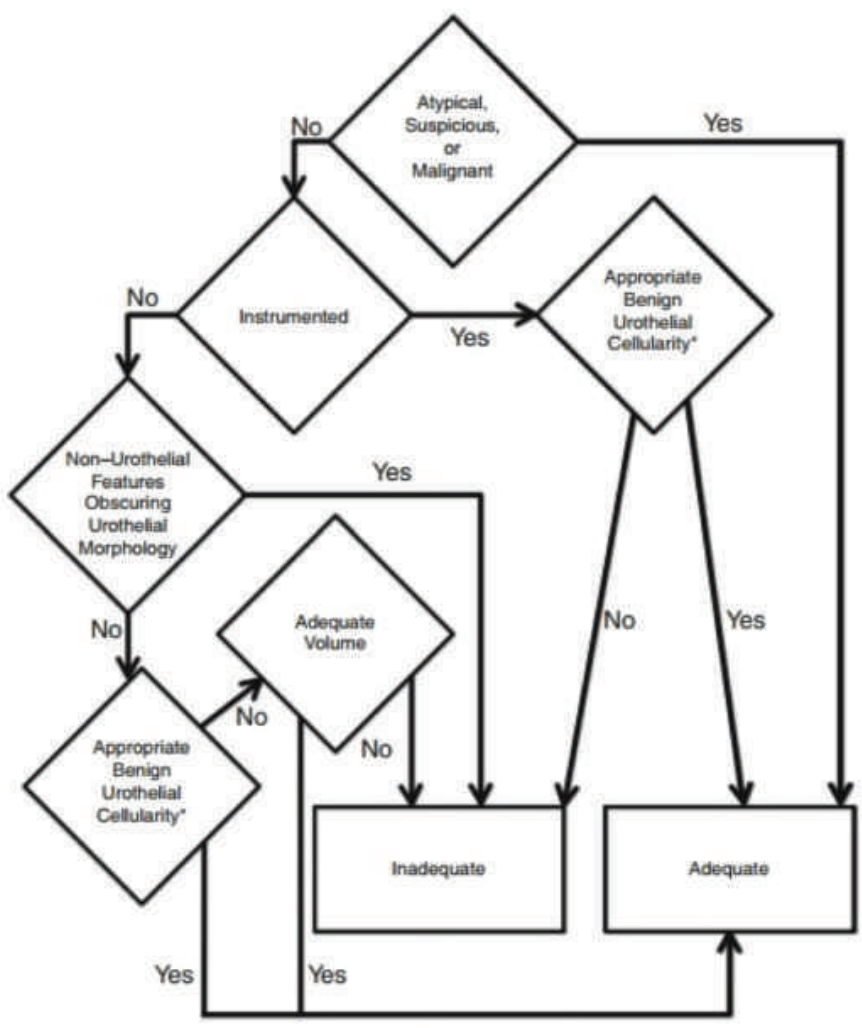

Figure 2: Adequacy algorithm proposed in TPS D 


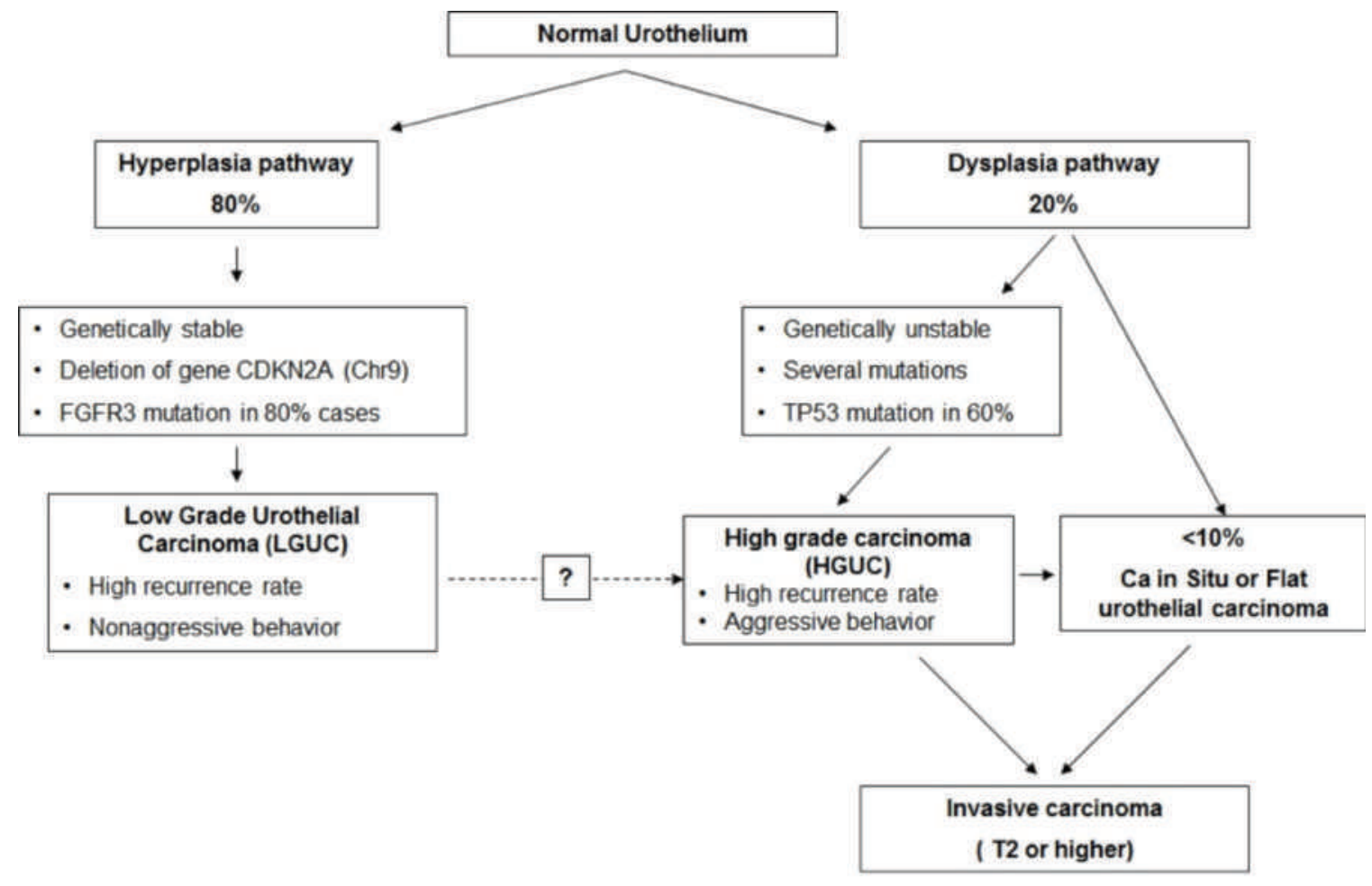

Figure 3: Current concepts on two different genetic pathways for Low grade and High gradeUrothelial carcinoma. Progression from LGUC to HGUC is rare $(<1-5 \%)$ and is shown with a dotted arrow. $D$

$\mathrm{N}: \mathrm{C}$ ratio, so in instrumented samples, 0.7 should be the strict cut off mark. ${ }^{12}$

\section{High Grade Urothelial Carcinoma (HGUC)}

The morphological features for severe dysplasia are somewhat well recognized and remained unchanged for several decades. High N/C ratio, nuclear pleomorphism, nuclear membrane irregularity, severe hyperchromasia, eccentrically located nuclei, prominent nucleoli, dense cytoplasm, mitotic figures, apoptotic bodies and extensive necrosis have been described as the features of HGUC., ${ }^{3,20,21}$ TPS has defined HGUC as similar cytological features as SHGUC but number of cell should be more than SHGUC i.e., more than 5-10 in number.12 (Table 2). HGUC with squamous differentiation and with glandular differentiation will show high grade urothelial cells mixed with cells with squamous features ( e.g., intercellular bridges, cytoplasmic keratin, spindling) and glandular features respectively. ${ }^{12}$

\section{Low Grage Urothelial Carcinoma}

Several authors have proposed different cytomorphological criteria for low grade urothelial carcinoma but none of these features are pathognomonic or diagnostic of LGUC. ${ }^{22}$ TPS recognizes that the only feature which can help in diagnosing low grade neoplasms is the presence of papillary cell clusters with fibrovascular cores in urine specimen. It is noteworthy that fibrovascular cores can be seen in any low grade papillary lesions including papilloma, papillary urothelial neoplasm of low malignant potential (PUNLMP), low grade urothelial carcinoma (LGUC) as per WHO/ISUP. So the nomenclature of this sixth category is low grade urothelial neoplasm (LGUN) rather than low grade urothelial carcinoma (LGUC). Fibrovascular cores in urine sample are however quite rare. The diagnosis of LGUN should be used sparingly and as a subcategory in combination with NHGUC to emphasize that there is no HGUC. This group of LGUN has the scope of further understanding and future genetic / molecular studies. ${ }^{12}$

\section{Other malignancies}

Primary bladder malignancies other than of urothelial origin ( nonurothelial carcinoma or non-UC ) comprise less than $5 \%$ of all bladder tumors and include squamous cell carcinoma, adenocarcinoma, small cell carcinoma, leiomyosarcoma, angiosarcoma, melanoma, hematologic malignancy etc. Their cytology features are similar as in other sites. Secondary carcinomas are mostly direct invasion from surrounding organs viz., prostate, cervix, uterus, gastrointestinal tract or metastasis from distant sites like melanoma, carcinomas from kidney, breast, stomach, lung etc. ${ }^{12}$

TPS also discusses the utility of different ancillary tests. To date no test is more specific sensitive and cheap than cytology. Among different types of available tests, only 4 types are approved in U.S. for the use in laboratory settings, namely, UroVysion FISH (U-FISH), ImmunoCyt, BTA test and NMP22. These methods are approved only 
for voided urine samples. The sensitivity and specificity of these tests vary widely in various literature. Testing must be well standardized, performed by well-trained persons and interpreted in correlation with patient's cystoscopy findings and cytology report and medical history. The costs of these tests also are a matter of concern especially in developing countries. The most commonly used test in U.S. is U-FISH which may help urologists in defining further management in cases with AUC and SHGUC cytological reports., ${ }^{1,12}$ Clinical management of different categories which have been summarized in table $3 .{ }^{1}$

\section{CONCLUSION}

The intention of The Paris Working Group is to provide a standardized guideline for reporting urine cytology. Hopefully The Paris System will be universally accepted by the cytopathologists. The Working Group with its ongoing studies will provide further evidence based information in future especially on relative risk and management protocol in each category as well as on ancillary tests.

\section{REFERENCES}

1. Barkan GA, Wojcik EM, Nayar R, Savic-Prince S, Quek ML, Kurtycz DF, Rosenthal DL.The Paris System for Reporting Urinary Cytology: The Quest to Develop a Standardized Terminology. Adv Anat Pathol. 2016;23:193-201. Crossref

2. van der Aa MN, Steyerberg EW, Bangma C, van Rhijn BW, Zwarthoff EC, van der Kwast TH. Cystoscopy revisited as the gold standard for detecting bladder cancer recurrence: diagnostic review bias in the randomized, prospective CEFUB trial. J Urol 2010;183:76-80. Crossref

3. Papanicolaou GN, Marshall VF. Urine sediment smears as a diagnostic procedure in cancers of the urinary tract. Science 1945;101:519-20. Crossref

4. Papanicolaou GN. Cytology of the urine sediment in neoplasms of the urinary tract. J Urol 1947;57:375-9. Crossref

5. Koss LG, Bartels PH, Sychra JJ, Wied GL. Diagnostic cytologic sample profiles in patients with bladder cancer using TICAS system. Acta Cytol 1978;22:392-7. Crossref

6. Murphy WM, Soloway MS, Jukkola AF, Crabtree WN, Ford KS. Urinary cytology and bladder cancer: The cellular features of transitional cell neoplasms. Cancer. 1984;53:1555-65. Crossref

7. Ooms EC, Veldhuizen RW. Cytological criteria and diagnostic terminology in urinary cytology. Cytopathology 1993;4:51-4. Crossref

8. Bhat AS, Manjunath J, Shettty M. Urine Cytology: A Review. Annals of Applied Bio-Sciences. 2016;3:R6-10.

9. Layfield LJ, Elsheikh TM, Fili A, Nayar R, Shidam V; Papanicolaou Society of Cytopathology. Review of the state of the art and recommendations of the Papanicolaou Society of Cytopathology for urinary cytology procedures and reporting: the Papanicolaou Society of Cytopathology Practice Guidelines Task Force. Diagn Cytopathol. 2004;30:24-30. Crossref

10. Owens, C. L., VandenBussche, C. J., Burroughs, F.H. and Rosenthal, D. L. A review of reporting systems and terminology for urine cytology . Cancer Cytopathology. 2013;121:9-14. Crossref

11. Glatz K, Willi N, Glatz D, Barascud A, Grilli B, Herzog M, Dalquen P, Feichter G, Gasser TC, Sulser T, Bubendorf L. An international telecytologic quiz on urinary cytology reveals educational deficits and absence of a commonly used classification system. Am J Clin Path 2006;126:294-301. Crossref

12. Rosenthal DL, Wojcik EM, Kurtycz DFI. (Eds). The Paris System for reporting Urine Cytology. New York. Springer; 2016.156p.

13. Netto GJ: Molecular genetics and genomics progress in urothelial bladder cancer. Semin Diagn Pathol 2013;30:313-20. Crossref

14. Cheng L, Zhang S, MacLennan GT, Williamson SR, Lopez-Beltran A, Montironi R: Bladder cancer: translating molecular genetic insights into clinical practice. Hum Pathol 2011;42:455-81. Crossref

15. Knowles MA: Molecular pathogenesis of bladder cancer. Int J Clin Oncol 2008;13:287-97 Crossref

16. Prather J, Arville B, Chatt G, et al: Evidencebased adequacy criteria for urinary bladder barbotage cytology. J Am Soc Cytopathol 2015;4:57-62. Crossref

17. VandenBussche CJ, Rosenthal DL, Olson MT. Adequacy in voided urine cytology specimens: the role of volume and a repeat void upon predictive values for high-grade urothelial carcinoma. Cancer Cytopathol. 2015;124:174-80. Crossref

18. Barkan GA. Enough Is enough: adequacy of voided urine cytology. Cancer Cytopathol. 2015;124:163-6. Crossref

19. Barkan GA, Wojcik EM, Rosenthal DL, Kurtycz DFI. Paris System: a new paradigm for urinary cytology. Cap Today. May 2016; Available from URL: Crossref

20. Koss LG, Melamed MR. (Eds0 Koss LG. Diagnostic Cytology and its Histopathologic Bases, 5th ed. Vol2. Philadelphia: Lippincott Williams and Wilkins, 2006. 846p.

21. Reid MD, Osunkoya AO, Siddiqui MT, Looney SW. Accuracy of grading of urothelial carcinoma on urine cytology: an analysis of interobserver and intraobserver agreement. Int J Clin Exp Pathol 2012;5:882-91. Crossref

22. McCroskey Z, Pambuccian SE, Kleitherms S, Antic T, Cohen MB, Barkan GA, Wojcik EM. Accuracy and interobserver variability of the cytologic diagnosis of low-grade urothelial carcinoma in instrumented urinary tract cytology specimens. Am J Clin Pathol. 2015;144:902-8. Crossref 